\title{
Study of Methods to Improve the Counselors' Scientific Research
}

\author{
Weiren Yuan 1 , Yaqing Zeng² \\ ${ }^{1}$ School of Economics and Management, Southwest Petroleum University, Chengdu, China \\ ${ }^{2}$ School of Chemistry and Chemical Engineering, Southwest Petroleum University, Chengdu, China \\ Email: ywr2010@163.com
}

How to cite this paper: Yuan, W. R., \& Zeng, Y. Q. (2017). Study of Methods to Improve the Counselors' Scientific Research. Creative Education, 8, 305-311. https://doi.org/10.4236/ce.2017.83024

Received: February 8, 2017

Accepted: March 3, 2017

Published: March 6, 2017

Copyright (c) 2017 by authors and Scientific Research Publishing Inc. This work is licensed under the Creative Commons Attribution International License (CC BY 4.0).

http://creativecommons.org/licenses/by/4.0/

\begin{abstract}
As the main body of moral education, counselors are the backbone of College Students' Ideological and Political Education. Counselor work plays a key role. It is very important to improve the ideological and political quality of college students, to promote the reform and development of higher education, to maintain the stability of school and society and to promote the all-round development of college students. At present, as the first line of moral education workers in colleges and universities, counselors need to shift from a single experience to complex research, in order to meet the needs of College Students' Ideological and Political Education in the new era. At first, this paper is based on the analysis of the present situation and analyzes the problems existing in the scientific research ability of college counselors from four aspects: the cognition of scientific research, the consciousness of scientific research, the spirit of scientific research, the relevant knowledge base and the scientific research environment. At last, the study puts forward the concrete countermeasures from four aspects: system guarantee, platform support, environmental pull and initiative promotion.
\end{abstract}

\section{Keywords}

Counselors, Scientific Research, Methods

\section{Introduction}

With the continuous development of higher education and the social situation, along with the change of higher education under the new situation (Adair, Sharpe, \& Huynh, 1989), a series of policies such as college enrollment and students employment distribution market, more arduous task of moral education in colleges and universities (Babad, Rosenthal, \& Inbar, 1982), the trend of popularization, diversification and internationalization of higher education is becoming 
more and more prominent, and a series of problems which have been obscured by the traditional "elite education" gradually emerge (Babad, 1998). The surge in enrollment quietly changed the nature and function of University. The education object group quality has undergone tremendous changes, showing a diversity of characteristics (Babad, 1993). College students from different regions, different families and their way of thinking, value orientation (Bakeman \& Gottman, 1997), moral character and behavior habits are vastly different. In addition, with the rapid development of international and domestic situation and the new media, the social thought is unprecedentedly active, changeable and complicated, which brings great challenge to the moral education in colleges and universities (Biddle, Chatzisarantis, \& Hagger, 2001). As the main body of moral education in colleges and universities, college counselors are the backbone of College Students' Ideological and Political Education (Biddle \& Goudas, 1997). It is very important to improve the ideological and political quality of college students, to promote the reform and development of higher education, to maintain the stability of school and society and to promote the all-round development of college students (Briere, Blais, Pelletier, \& Vallerand, 1995). With the transformation and development of the society, various social thoughts grow stealthily (Brophy \& Good, 1974). The complicated and changeable social environment makes the ideological and political education work of college students become more and more complex, and the contradictions and problems are outstanding (Bryan \& Solmon, 2007). With the change of Higher Education under the new situation, a series of policies such as college enrollment and students employment distribution market (Carreiro da Costa, Marques da Costa, Diniz, \& Piéron, 1998), the popularization of higher education has brought new challenges to college students' work. In such a situation, as the first line of moral education workers in colleges and universities, counselors need to shift from a single experience to complex research, in order to meet the needs of College Students' Ideological and Political Education in the new era.

\section{College Counselors' Scientific Research Ability}

The scientific research ability of college counselors is formed and developed in scientific research activities. Therefore, there is an inherent unity with the scientific research process (Cloes, Ledent, \& Piéron, 2004). Through the summary of existing research and reference analysis of the structural elements of the scientific research ability of college counselors of the scholar Borough in Reflections on improving the scientific research ability of Counselors, in this study, the structural elements of the scientific research ability of college counselors can be divided into five aspects: the ability of problem finding; the ability of collecting and sorting the documents; the ability of investigation and statistical analysis and the ability of writing.

1) The ability of problem finding: Any research starts from the problem, so the problem finding ability is the premise and foundation of scientific research. The problem finding ability of college counselors refers to the ability of the col- 
lege counselors to find out all kinds of contradictions in the theory and practice of the work and transform the related problems into the research questions.

2) The ability of collecting and sorting of literature: The ability of collecting and sorting of literature is the ability to obtain and deal with the relevant documents and materials through the Internet and the network.

3) The ability of investigation and statistical analysis: Research and statistical analysis is the ability to study design through a planned and step-by-step approach. Investigate the research object, collect and sort out the relevant information. We can use qualitative and quantitative analysis to analyze the relationship between various factors and their relationship and find out the essence and law of things.

4) The ability of text writing: The ability to write text is the ability of the researcher to translate the research results directly or indirectly into the papers, research reports and other publications. This is an essential skill in the process of scientific research.

\section{The Main Problems in the Scientific Research of College Counselors in Southwest Petroleum University}

1. Less research time

The Ministry of education No. 24 provides instructors eight main responsibilities include psychological counseling, safety education, financial aid, student employment guidance, class management and party building. However, in practical work, as long as all the work related to students, counselors should be responsible for it. Counselors led by all departments, agencies and departments and play the role of communication between the upper and lower staff (Cooper, 1979). They are students' "big sister". That is a person with multiple responsibilities. Anecdotal popular saying goes: two open busy lights. Counselors work during the day and night as well as working days and weekends, which is a true portrayal of counselors work. It can be said that the work of counselor is many things, long, strong and heavy responsibility. The counselor is busy all day long to deal with the complicated and trivial affairs of student and has no time and energy to devote to the ideological and political education work. Therefore, counselors will not conduct an in-depth study of the objective laws of Ideological and Political Education (Covington \& Omelich, 1979).

\section{Lack of scientific research consciousness}

The scientific research consciousness of counselors is that the counselors should have the consciousness of exploring and studying the various situations and problems in the work of students in a timely manner. Many experts and scholars have shown that the Counselor's scientific research consciousness is weak, many scientific research papers and the results are to the Title Evaluation needs. Many instructors believe that their main task is to manage the students, and scientific research should be handed over to professional teachers. It is often referred to as "heavy management, light academic" thought. Some counselors are accustomed to the simple use of ready-made experience, methods and theo- 
ries, did not realize that the ability of improve scientific research can bring higher efficiency for their work. They also lack the consciousness which is to use scientific method to discover problems, analyze problems and solve problems.

3. Scientific research ability is not strong

With the improvement of the access threshold, at present, most of the counselors are master's degree students and even some of them are doctors. It can be said that the all the counselors have higher degree and the scientific research capacity cannot be ignored. However, many counselors are not professional background and theoretical foundation is not solid. Most of its research is a description of a phenomenon, theoretical and academic is not strong. Due to the lack of knowledge of the system, it is impossible to deal with the problem and analyze the data with professional knowledge and cannot combine the personal work and scientific research. At the same time, mobility of "the diversity of the export of counselors, the development of autonomy" is high, and many of the counselors is considering the problem of diversion after age. Counselors pay more attention to their future development direction and prepare for their own teaching, research, management and other positions. Ideological and political education research has a lot of room for improvement.

4. Scientific atmosphere is not strong

Due to the professional background of counselors and the heavy workload, the time and energy of the instructors are limited and more is to discuss practical problems together. In the training of counselors, more attention is paid to the cultivation of students' work skills. The training, guidance and planning of scientific research of counselor are obviously insufficient. From the school level, the school does not have counselors as an important part of the school scientific research team. In the case of project reporting, evaluation and other aspects, the policy orientation of the school is not enough and the construction of the scientific research team is lack of corresponding guarantee system. At present, the scientific research work of counselors is mostly in the state of spontaneous and loose rearing. This kind of atmosphere directly leads to the lack of scientific research consciousness, and the research achievement is not high.

\section{Methods to Improve the Scientific Research Ability of Counselors}

1. Improve the system of scientific research ability of College Counselors

System construction is the external power for the promotion of scientific research ability of College Counselors. A large extent, whether national or local educational administrative departments or colleges, they formulate relevant policies and system improvement, not only for scientific research ability of university counselors to indicate the development, but also to enhance the scientific research ability provides a powerful impetus to support. Therefore, based on the existing system, to further improve the relevant system is very important (Darley \& Fazio, 1980).

2. Building a platform for promoting the scientific research ability of College 


\section{Counselors}

Scientific research platform is an important carrier for college counselors to carry out scientific research practice, which is conducive to the promotion and development of scientific research ability of College counselors. Thus, it is necessary to build an integrated platform with the scientific research work of college counselors to provide systematic and targeted help for the improvement of scientific research ability. Researchers seek a digital environment where ideas can be exchanged, examined, and applied with tools that empower scientific and technical knowledge. It allows researchers to find and analyze data; access the leading Ebooks and journal articles published; and manage the research and showcase the profile via free services. The platforms make data and content easier to search, access, analyze, and share.

3. To create a good atmosphere for the promotion of scientific research ability of College Counselors

For college counselors, to create a good atmosphere conducive to the promotion of their scientific research ability is the key to promote their individual development and professional specialization of counselors professional development process. Although the current college counselors is still in transition from "experience" to "research" and the national related policy documents have to be further improved and implemented. The college counselors are not from the affairs of the release of enough time and energy in their work. Therefore, it is necessary to start from the two aspects of macro policy optimization and the improvement of the school environment and further create a good atmosphere to enhance the scientific research ability of college counselors.

4. Promoting the active promotion of scientific research ability of College Counselors

Colleges and universities as an important guide of scientific research ability development shoulder the important responsibility to cultivate and promote the scientific research ability development and standardize guidance. Colleges and universities provide a good platform for the development of scientific research ability and environmental protection. However, as a dynamic individual, the development of scientific research ability is based on the strong demand and willingness of independent development. Therefore, college counselors must play an active role to achieve the initiative of scientific research ability.

\section{Conclusion}

To enhance the scientific research ability of college counselors is a higher requirement for the ability and quality of College Counselors in the new period and it must be paid enough attention. College counselors enhance their ability of scientific research, which is not only conducive to promote the counselors Professionalism development, but also contributes to the innovation of College Counselors' work and improves the work of ideological and political education. This study is mainly to promote the scientific research ability of College Counselors. If we want to really improve the effectiveness, the following research 
needs to consider the development of the evaluation index system of the scientific research ability of college counselors and the development stage and development vision of the scientific research ability, promoting the professional development of college counselors by improving the level of scientific research.

\section{References}

Adair, J. G., Sharpe, D., \& Huynh, C. L. (1989). Placebo, Hawthorne, and Other Artifact Controls: Researchers' Opinions and Practices. Journal of Experimental Education, 57, 341-335. https://doi.org/10.1080/00220973.1989.10806515

Babad, E. Y. (1993). Teachers' Differential Behaviour. Educational Psychology Review, 5, 347-376. https://doi.org/10.1007/BF01320223

Babad, E. Y. (1998). Preferential Affect: The Crux of the Teacher Expectancy Issue. In J. Brophy (Ed.), Advanced in Research on Teaching: Expectations in the Classroom (Vol. 7, pp. 183-214). Greenwich: JAI Press.

Babad, E. Y., Rosenthal, R., \& Inbar, J. (1982). Pygmalion, Galatea, and the Golem: Investigations of Biased and Unbiased Teachers. Journal of Educational Psychology, 74, 459-474. https://doi.org/10.1037/0022-0663.74.4.459

Bakeman, R., \& Gottman, J. M. (1997). Observing Interaction: An Introduction to Sequential Analysis (2nd ed.). Cambridge: Cambridge University Press. https://doi.org/10.1017/CBO9780511527685

Biddle, S. J., \& Goudas, M. (1997). Effort Is Virtuous: Teacher Preferences of Pupil Effort, Ability and Grading in Physical Education. Educational Research, 39, 350-355. https://doi.org/10.1080/0013188970390310

Biddle, S., Chatzisarantis, N., \& Hagger, M. (2001). Théorie de l'autodétermination dans le domaine du sport et de l'exercice physique. In F. Cury, \& P. Sarrazin (Eds.), Théories de la motivation et pratique sportive. Etat des recherches (pp. 19-55). Paris: PUF.

Briere, N., Blais, M., Pelletier, L., \& Vallerand, R. (1995). Developpement et Validation d'une Mesure de Motivation Intrinsèque, Extrinsèque et d'Amotivation en Contexte Sportif: L'Echelle de Motivation dans les Sports (EMS). International Journal of Sport Psychology, 26, 465-489.

Brophy, J., \& Good, T. (1974). Teacher-Student Relationships: Causes and Consequences. New York: Holt, Rinehart \& Winston.

Bryan, C. L., \& Solmon, M. A. (2007). Self-Determination in Physical Education: Designing Class Environments to Promote Active Lifestyles. Journal of Teaching in Physical Education, 26, 260-278. https://doi.org/10.1123/jtpe.26.3.260

Carreiro da Costa, F., Marques da Costa, C., Diniz, J. A., \& Piéron, M. (1998). Uneanalyse de la qualité du feedback. In C. Amade-Escot, J.-P. Barrué, J.-C. Bos, F. Dufor, M. Dugrand, \& A. Terrisse (Eds.), Recherches enEPS: Bilan et perspectives (pp. 215-224). Paris: Éditions EP \& S.

Cloes, M., Ledent, M., \& Piéron, M. (2004). Motiver pour éduquer, un éclairage qualitatif. In G. Carlier (Ed.), Si l'on parlait du plaisir d'enseigner l'education physique (pp. 65-73). Montpellier: Éditions AFRAPS.

Cooper, H. (1979). Pygmalion Grows up: A Model for Teacher Expectation Communication and Performance Influence. Review of Educational Research, 49, 389-410. https://doi.org/10.3102/00346543049003389

Covington, M. V., \& Omelich, C. L. (1979). It's Best to Be Able and Virtuous Too: Student and Teacher Evaluative Responses to Successful Effort. Journal of Educational Psychology, 71, 688-700. https://doi.org/10.1037/0022-0663.71.5.688 
Darley, J. M., \& Fazio, R. H. (1980). Expectancy-Confirmation Processes Arising in the Social Interaction Sequence. American Psychologist, 35, 867-881.

https://doi.org/10.1037/0003-066X.35.10.867

Submit or recommend next manuscript to SCIRP and we will provide best service for you:

Accepting pre-submission inquiries through Email, Facebook, LinkedIn, Twitter, etc. A wide selection of journals (inclusive of 9 subjects, more than 200 journals)

Providing 24-hour high-quality service

User-friendly online submission system

Fair and swift peer-review system

Efficient typesetting and proofreading procedure

Display of the result of downloads and visits, as well as the number of cited articles

Maximum dissemination of your research work

Submit your manuscript at: http://papersubmission.scirp.org/

Or contact ce@scirp.org 